АКУШЕРСТ В
ГИНЕКОЛОГИЯ
РЕПРОДУКЦИЯ Включен в перечень ведущих рецензируемых журналов и изданий ВАК $2016 \cdot$ Tom $10 \cdot$ № 1

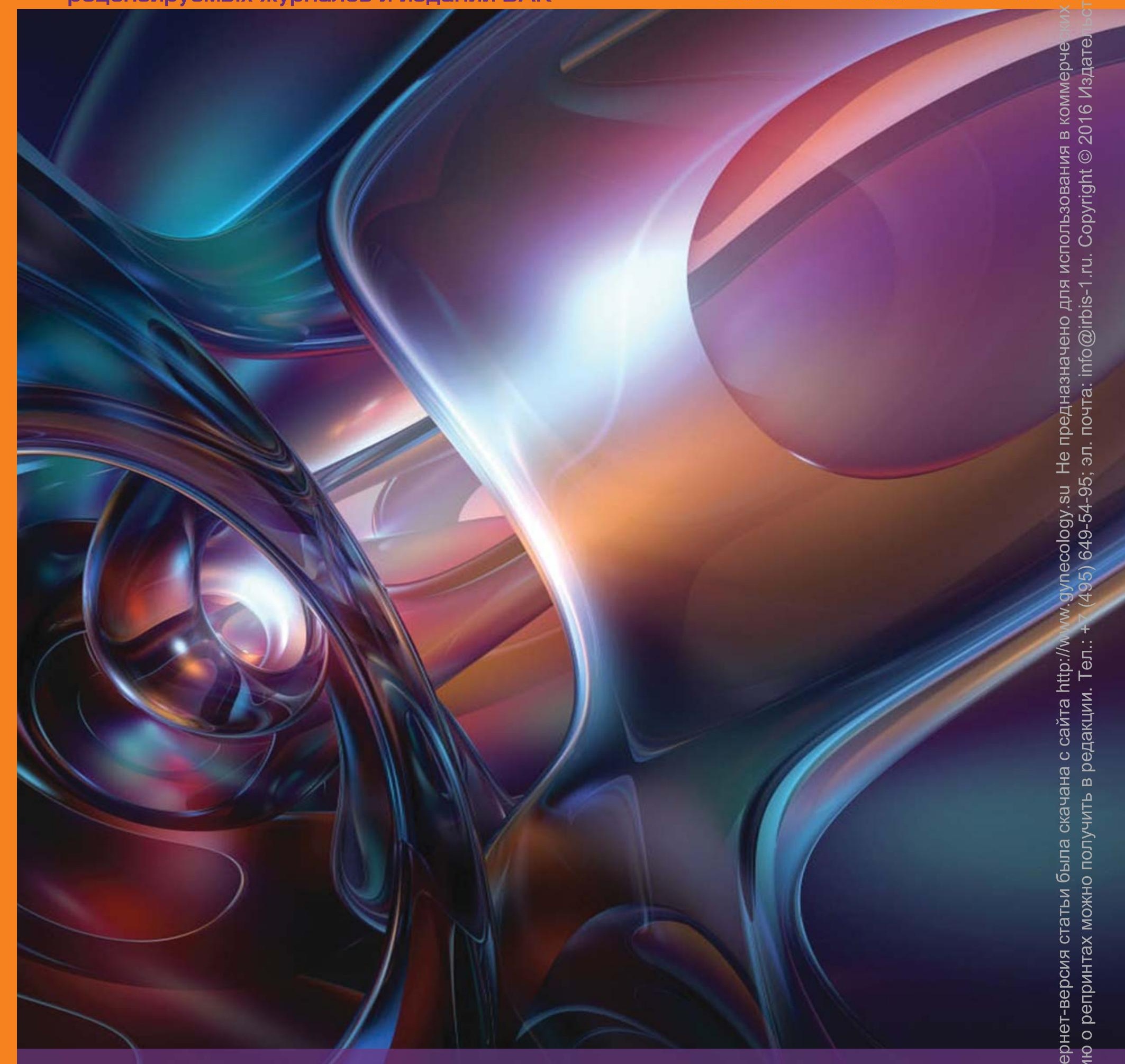

OBSTETRICS, GYNECOLOCY AND REPRODUCTION 产 ISSN 2313-7347 


\title{
MICROVESICLES AND THROMBOSIS IN OBSTETRIC-GYNECOLOGICAL COMPLICATIONS
}

\author{
Anat Aharon ${ }^{1,2}$, Benjamin Brenner ${ }^{1,2}$ \\ ${ }^{1}$ Microvesicles Research Laboratory, Department of Hematology and Bone Marrow Transplantation, \\ Rambam Health Care Campus, Haifa, Israel \\ ${ }^{2}$ Bruce Rappaport Faculty of Medicine, Technion, Israel Institute of Technology, Haifa, Israel
}

\section{Summary}

Microvesicles (MVs), including microparticles and exosomes, are secreted from a variety of cells. They are present in the blood circulation under normal physiological conditions, and their levels increase in a wide range of disease states. MVs contain proteins, growth and apoptotic factors, DNA fragments, microRNAs as well as messenger RNAs (mRNAs); therefore, they may function as regulators in cell-cell communication and mediators of cell signaling during multiple biological processes. The current review focuses on the role of MVs in healthy pregnancy and gestational vascular complications and discusses the involvement of MVs in thrombosis, hemostasis and cell function that overall reflect the placental-maternal crosstalk.

\section{Key words}

Microvesicles (MVs), exosomes, microparticles (MPs), hemostasis, thrombosis, placenta, pregnancy, gestational vascular complications (GVC), microRNA (miRNA).

Received: 18.01.2016; in the revised form: 08.02.2016; accepted: 12.02.2016.

\section{Conflict of interests}

The authors declared that they do not have anything to disclosure regarding funding or conflict of interests with respect to this manuscript.

All authors contributed equally to this article.

For citation

Aharon A., Brenner B. Microvesicles and thrombosis in obstetric-gynecological complications. Akusherstvo, ginekologiya i reproduktsiya / Obstetrics, gynecology and reproduction. 2016; 1: 5-10.

Corresponding author

Address: P.0. Box 9602, Haifa 31096, Israel.

E-mail address: a_aharon@yahoo.com (Anat Aharon)

\section{МИКРОВЕЗИКУЛЫ И ТРОМБОЗ ПРИ ОСЛОЖНЕНИЯХ В АКУШЕРСТВЕ И ГИНЕКОЛОГИИ}

Аарон А. ${ }^{1,2}$, Бреннер Б. ${ }^{1,2}$

1 Лаборатория по исследованию микровезикул, отделение гематологии и трансплантации костного мозга, Медицинский городок Рамбам, Хайфа, Израиль

${ }^{2}$ Медицинский факультет им. Брюса Раппапорта, Технион, Хайсра, Израиль 


\section{Резюме}

Микровезикулы (МВ), включая микрочастицы и экзосомы, секретируются из множества клеток. Они присутствуют в кровотоке при нормальных фризиологических условиях и их уровни увеличиваются при многих заболеваниях. МВ содержат белки, факторы роста и апоптопические факторы, фррагменты ДНК, микроРНК, а также информационные РНК; следовательно они могут регулировать межклеточные коммуникации и являться посредниками для передачи сигналов клеток в течение разнообразных биологических процессов. Данный обзор сфокусирован на роли МВ для здоровой беременности и при гестационных сосудистых осложнениях, в нем обсуждается участие МВ в тромбозах, гемостазе и ффункционировании клеток, которое по сути своей отражает взаимное влияние плаценты и организма матери.

\section{Ключевые слова}

Микровезикулы, экзосомы, микрочастицы, гемостаз, тромбоз, плацента, беременность, гестационные сосудистые осложнения, микроРНК.

Статья поступила: 18.01.2016 г.; в доработанном виде: 08.02.2016 г.; принята к печати: 12.02 .2016 г.

\section{Конфликт интересов}

Авторы заявляют об отсутствии необходимости раскрытия фринансовой поддержки или конфрликта интересов в отношении данной публикации.

Все авторы сделали эквивалентный вклад в подготовку публикации.

\section{Для цитирования}

Аарон А., Бреннер Б. Микровезикулы и тромбоз при осложнениях в акушерстве и гинекологии. Акушерство, гинекология и репродукция. 2016; 1: 5-10.

\section{Extracellular vesicles}

Extracellular membrane vesicles (EVs) are secreted from different types of cells, including blood cells, endothelial, trophoblast, cardiac and tumor cells [1,2]. EVs are present in the blood circulation and other biological fluids under normal physiologic conditions, and their levels increase in a wide range of disease states. EVs contain proteins, growth and apoptotic factors, DNA fragments, microRNAs as well as messenger RNAs (mRNAs); therefore, they may function as regulators in cell-cell communication and mediators of paracrine signaling during multiple biological processes [1,2]. Depending on their size, mechanism of release and protein compositions, EVs can be divided into three subpopulations:

1) exosomes,

2) microparticles (MPs)

3) apoptotic bodies $[3,4]$.

1) Exosomes have a size of $30-100 \mathrm{~nm}$ in diameter and derive from endosomal compartments [5]. 2) Microparticles (MPs) are larger $(100 \mathrm{~nm}-1 \mu \mathrm{m})$ and are released from the cell surface plasma membrane via a process called vesiculation [6]. MPs are shed from cell membrane upon activation or apoptosis and can induce cell signaling that may lead to a variety of processes including invasion, migration, proliferation, angiogenesis or apoptosis [7,8]. Thus, MPs are involved in thrombosis, inflammation and vascular dysfunction [2]. MPs contain characteristic proteins which are enriched in lipid rafts and are exposed on their surface [9]. Like exosomes, MPs contain typical marker proteins similar to the secreting cells. In addition, emerging evidence suggests that MPs are not simply a consequence of a disease, but rather a factor contributing to its pathological processes. Thus, MPs serve as both as markers and mediators of vascular complications [10] and may play a significant role in the maternal placental crosstalk [11]. 3). Apoptotic bodies are released from blebs of apoptotic cells and have a size of $1-5 \mu \mathrm{m}$ in diameter [12]. The review is focused on MPs and exosomes which are termed collectively microvesicles (MVs). Upon release, MVs can interact with target cells via a receptor-mediated mechanism $[13,14]$ or they can directly fuse with the plasma membrane of target cells and release their content into the recipient cell [4]. Alternatively, MVs can be internalized via endocytosis [15]. After internalization, MVs can fuse with endosomes to release the content into the cytosol of target cells; they can be transferred to lysosomes and are degraded.

\section{Microvesicles and thrombosis}

Tissue factor (TF), the main activator of the coagulation cascade, is expressed on non-vascular cells, activated cells within the vessel wall (such as leukocytes and endo- 
thelial cells) and circulating MVs [16]. TF-bearing MVs arise from raft-rich regions of the plasma membrane enriched with TF, P-selectin glycoprotein ligand-1 and phosphatidylserine [17] and play a central role in the initiation of the coagulation cascade. These MVs have been shown to accumulate during cell injury-induced clot formation and promote thrombotic events [18,19]. In addition, TF-bearing MVs participate in platelet thrombus formation by binding to P-selectin on the platelet surface [9]. Despite circulation of TF-bearing MVs in healthy people, TF activity remains undetectable and it activates upon recruitment to a site of vascular injury. However, in pathological states, MVs bearing active TF confer a predisposition to thromboembolic events [20]. The procoagulant properties of the MVs may also be attributed to the hemostatic balance between pro- and anti-coagulant mechanisms. It was found that the MV hemostatic ratio between TF and its inhibitor TF pathway inhibitor (TFPI) was $<1$ in healthy controls but significantly increased in patients with cardiovascular complications (CAD), diabetic CAD (DCAD) and patients with diabetic foot [21], patients with solid tumors [22] as well as hematologic malignancy [23]. Additionally, part of MVs express high levels of negatively charged phospholipids such as phosphatidylserine, which provides a catalytic site for coagulation complexes (TF/ VIla, prothrombinase and tenase), thereby indirectly enhancing coagulation activation [24].

High levels of circulating MVs specifically annexin V-bearing MV, endothelial and platelet MVs have been associated with an increased risk of VTE in patients with factor V Leiden and prothrombin G20210A mutation [25], and in carriers of natural anticoagulant deficiencies (antithrombin, protein $\mathrm{C}$ and protein $\mathrm{S}$ defect) [26], suggesting a possible contribution of MVs to the hypercoagulability of genetic thrombophilia. Additionally, an increase in platelet and endothelial MVs was also found in patients with antiphospholipid syndrome (APS) and antiphospholipid antibodies (aPL), a syndrome which is associated with thrombosis and recurrent pregnancy loss [27].

\section{Microvesicle cell origin \\ and thrombogenicity in healthy pregnancy and gestational vascular complications}

Studies measuring the numbers of circulating MVs and their cell origin in normal and complicated pregnancy are inconsistent and demonstrate high variation in their results mainly because of the lack of standardization and sensitive tools for MV analysis [28]. The levels of total, platelet-, endothelial-, leukocyte-derived and tissue factorbearing MVs, in normal healthy pregnancy are found to be higher in the 1st trimester as compared to the non-pregnant state and gradually increase during pregnancy, with the highest values reached in the 3rd trimester [29]. Compared to normal pregnancies, in women with gestational vascular complications (GVC) such as hypertension and pre-eclampsia further increases were found in the levels of endothelial MVs that may indicate a vascular injury [30-34] and in the levels of monocyte and leukocyte MVs that may indicate inflammatory response [31,35-37]. Moreover, in non-pregnant women with a history of recurrent pregnancy loss, a significant increase in total annexin $\mathrm{V}$, TF and endothelial MVs was demonstrated compared to parous controls [38-40]. MVs obtained from healthy pregnant women displayed a higher procoagulant activity compared to those of non-pregnant females $[29,41]$ and an increase in the MV TF/TFPI ratio. The MV procoagulant activity as well as the TF/TFPI ratio appeared to be further elevated in MVs of women with GVC $[30,41,42]$. The presence of increased levels of endothelial, TF and phosphatidylserine expressing MVs at a gap of at least 3 months after the pregnancy loss suggests a continued chronic endothelial damage/activation [38].

Circulating MVs of pregnant women include MVs of placental syncytiotrophoblast origin that can be detected in maternal circulation from second trimester and their number increases during the third trimester [43]. Exosomes released by trophoblasts carry molecules involved in placental physiology and play a key role in cellcell communication within the placental micro-environment and in maternal-fetal cross-talk [44]. We found that levels of placental trophoblast MVs were similar in all pregnancy groups [31]. However, other publications reported excess shedding of syncytiotrophoblast MVs in early-onset pre-eclampsia, but not in woman with normotensive intrauterine growth restriction $[43,45]$. Higher amounts of circulating syncytiotrophoblast MVs in maternal blood might lead to endothelial dysfunction, monocyte stimulation and an excessive maternal inflammatory reaction [46,47]. Syncytiotrophoblast MVs bearing TF, and other coagulation factors may reflect the delicate hemostatic balance between maternal and placental cells $[42,48]$. Whereas the relative contribution of syncytiotrophoblast MVs bearing TF was substantial in healthy pregnant women, syncytiotrophoblast MVs are one of the most increased MVs during pre-eclampsia (PE) and may play an important role in the pathogenesis of this syndrome [49].

A significant increase in the maternal source of TF-bearing MVs in pregnant women with GVC potentially reflects the systemic nature of such pathologies [42]. Syncytiotrophoblast MVs were found to trigger thrombin generation in normal plasma in a TF-dependent manner, which was more pronounced in syncytiotrophoblast MVs shed from pre-eclamptic placenta, indicating that TF activity is expressed by these MVs [41]. The MV content and their effects on endothelial and trophoblast cell function vary according to the physiological/pathological state of a pregnant woman. There is sustained evidence that MVs of women with GVC reflect the pathophysiological state of the patients.

\section{Microvesicles, pregnancy and inflammation}

Pre-eclampsia altered the production of immunoregulatory cytokines and angiogenic factors, which 
resulted in poor trophoblastic invasion at the first stage of the disease, and affected systemic maternal inflammatory response at the second stage, that included release of necrotic and/or apoptotic syncytiotrophoblast bodies into the maternal circulation that induced maternal vascular endothelial injury [50,51].

We found that MVs obtained from women with GVC demonstrated higher levels of inflammatory and angiogenic proteins compared with those of healthy pregnant women [52]. Placental MVs can modulate basal peripheral immune cell activation and responsiveness to lipopolysaccharide (LPS) during normal pregnancy; in preeclampsia, this effect is exacerbated. Placental syncytiotrophoblast MVs generated in-vitro from normal placentas, stimulate peripheral blood monocytes, which may indicate contribution of syncytiotrophoblast MVs to the systemic maternal inflammation. Syncytiotrophoblast MVs derived from pre-eclamptic placentas were found to up-regulate the cell surface expression of intercellular adhesion molecule 1 (ICAM-1, CD54) of peripheral blood monocytes, and stimulate the secretion of pro-inflammatory interleukin (IL)-6 and IL-8 from these cells [46]. Inflammatory priming of peripheral blood mononuclear cells (PBMCs) during pregnancy is established by the first trimester and is associated with early inhibition of IFN- $\gamma$ production. The inflammatory response is enhanced in pre-eclampsia with loss of the IFN- $\gamma$ suppression [53]. Circulating syncytiotrophoblast membrane MVs (STBMs) bind to monocytes and stimulate the production of inflammatory cytokines [53]. MVs drawn from pre-eclamptic women induce vascular hyporeactivity in vessels of pregnant mice through an overproduction of nitric oxide (NO) [54]. MVs derived from hypoxic trophoblasts induce a more intense and rapid inflammatory response of PBMCs than MVs from normal trophoblasts. This difference might explain the exaggerated systemic inflammatory response as a result of placental hypoxia in pre-eclampsia [55]. Apoptosis is crucial in mediating immune privilege of the fetus during pregnancy. Exosomes secreted by human placenta carry functional Fas ligand, trail molecules and convey apoptosis in activated immune cells, suggesting exosomemediated immune privilege of the fetus.

MVs of healthy pregnant women were found to reduce apoptosis, increase migration, and induce tube formation of endothelial cells. These processes were suppressed by MVs of women with GVC. In early-stage trophoblasts, MVs of healthy pregnant women decreased apoptosis compared with untreated cells and induced higher migration. This effect was mediated through extracellular signal-regulated kinase pathway. Conversely, MVs of women with GVC increased term trophoblast apoptosis compared to cells exposed to MVs of healthy pregnant women and inhibited early-stage trophoblasts migration. Trophoblast debris obtained from culturing placental explants of normal placentas shows markers of apoptosis and is phagocytosed by macrophages or endothelial cells, producing a tolerant phenotype in the phagocyte. When normal placental explants are cultured with antiphospholipid antibodies (a maternal risk factor for pre-eclampsia), or IL-6 (which increases in the serum of pre-eclamptic women), the death process in the syncytiotrophoblasts results in more necrotic debris which in turn leads to activation of endothelial cells.

\section{Microvesicles and microRNAs}

Non-coding microRNAs (miRNAs) have a size of $\sim 22$ nucleotides in length and normally function as negative intracellular regulators of target mRNA expression at the post-transcriptional level via binding to the 3'UTR of target mRNAs through base pairing, which results in target mRNAs cleavage or translation inhibition [56]. miRNAs play critical roles in many key biological processes: cell growth, tissue differentiation, cell proliferation, embryonic development and apoptosis. Each miRNA can control hundreds of gene targets [57-60]. As such, the mutation of miRNAs, the dysfunction of miRNA biogenesis and the dysregulation of miRNAs and their targets may result in various diseases $[57,58,61,62]$. The detection of extracellular miRNAs in serum or breast milk suggests that miRNAs have a biological function and can be mediators for cell signaling in target cells and biomarkers for disease $[61,63]$. In blood circulation, miRNAs are protected from RNase degradations due to the inclusion into MVs, which serve as carriers for regulatory RNAs $[1,64]$. Several studies have shown that circulating MVs serve as transport vehicles for large numbers of specific miRNAs and have been associated with vascular diseases [63-66]. miRNA profiles of MVs can significantly differ from their maternal cells, indicating an active mechanism of selective 'packaging' from cells into MVs $[1,65,67]$. This suggests a unique mechanism of transferring gene-regulatory function from releasing cells to target cells via MVs circulating in blood $[59,66]$. Human villous trophoblasts express and secrete placenta-specific miRNAs into maternal circulation via exosomes $[30,67]$. However, the research of MV miRNA involvement in pregnancy is in its first steps and focuses on screening for miRNAs that are unique for pregnancy. One of these studies described specific miRNA profiles in the placenta and maternal plasma. It has been found that numerous miRNAs, which are exclusively expressed during pregnancy, are clustered in chromosomal regions. The three major clusters are: the chromosome 19 miRNA cluster (C19MC), miR-371-3 cluster, which is also localized on chromosome 19, and the C14MC cluster. miRNA members of these clusters are detected in the placenta and the serum $[58,59]$. A specific miRNA was found to be correlated with the growth of the placenta and pregnancy age and part of this miRNA is also expressed in a variety of tumors [59].

In summary, MVs seem to play a pivotal role in the course of pregnancy, which could potentially result in gestational vascular complications and may serve as a biomarker for early diagnosis of such pathologies. 


\section{References:}

1. Valadi H., Ekstrom K, Bossios A., et al. Exosome-mediated transfer of mRNAs and microRNAs is a novel mechanism of genetic exchange between cells. Nat Cell Biol 2007 Jun; 9 (6): 654-9

2. Piccin A., Murphy W.G., Smith O.P. Circulating microparticles: pathophysiology and clinical implications. Blood Rev. 2007 May; 21 (3): 157-71.

3. Simpson R.J., Jensen S.S., Lim J.W. Proteomic profiling of exosomes: current perspectives. Proteomics 2008 0ct; 8 (19): 4083-99.

4. Cocucci E., Racchetti G., Meldolesi J. Shedding microvesicles: artefacts no more. Trends Cell Biol. 2009 Feb; 19 (2): 43-51.

5. Denzer K., Kleijmeer M.J., Heijnen H.F., et al. Exosome: from internal vesicle of the multivesicular body to intercellular signaling device. J Cell Sci. 2000 0ct; 113 Pt 19: 3365-74.

6. Schara K., Jansa V., Sustar V. et al. Mechanisms for the formation of membranous nanostructures in cell-to-cell communication. Cell Mol Biol Lett. 2009; 14 (4): 636-56.

7. Essayagh S. Xuereb J.M., Terrisse A.D. et al. Microparticles from apoptotic monocytes induce transient platelet recruitment and tissue factor expression by cultured human vascular endothelial cells via a redox-sensitive mechanism. Thromb Haemost. 2007 0ct; 98 (4): 831-7.

8. Simak J., Gelderman M.P. Cell membrane microparticles in blood and blood products: potentially pathogenic agents and diagnostic markers. Transfus Med Rev. 2006 Jan; 20 (1): 1-26

9. Del Conde I., Shrimpton C.N., Thiagarajan P. et al. Tissue-factor-bearing microvesicles arise from lipid rafts and fuse with activated platelets to initiate coagulation. Blood. 2005 Sep 1; 106 (5): 1604-11.

10. Burger D., Schock S., Thompson C.S. et al. Microparticles: biomarkers and beyond. Clin Sci (Lond). 2013 Apr; 124 (7): 423-41.

11. Aharon A., Brenner B. Microparticles and pregnancy complications. Thromb Res. 2011 Feb; 127 Suppl 3: 67-71.

12. Hristov M., Erl W., Linder S. et al. Apoptotic bodies from endothelial cells enhance the number and initiate the differentiation of human endothelial progenitor cells in vitro. Blood. 2004 Nov 1; 104 (9): 2761-6.

13. Janowska-Wieczorek A., Wysoczynski M., Kijowski J. et al. Microvesicles derived from activated platelets induce metastasis and angiogenesis in lung cancer. Int $J$ Cancer. 2005 Feb 20; 113 (5): 752-60.

14. Segura E., Guerin C., Hogg N. et al. CD8+ dendritic cells use LFA-1 to capture MHCpeptide complexes from exosomes in vivo. J Immunol. 2007 Aug 1; 179 (3): 1489-96.

15. Morelli A.E., Larregina A.T., Shufesky W.J. et al. Endocytosis, intracellular sorting, and processing of exosomes by dendritic cells. Blood. 2004 Nov 15; 104 (10): 3257-66.

16. Chou J., Mackman N., Merrill-Skoloff G. et al. Hematopoietic cell-derived microparticle tissue factor contributes to fibrin formation during thrombus propagation. Blood. 2004 Nov 15; 104 (10): 3190-7.

17. Lopez J.A., del Conde I., Shrimpton C.N Receptors, rafts, and microvesicles in thrombosis and inflammation. J Thromb Haemost. 2005 Aug; 3 (8): 1737-44.

18. Furie B., Furie B.C. Role of platelet P-selectin and microparticle PSGL-1 in thrombus formation. Trends Mol Med. 2004 Apr; 10 (4): 171-8.

19. Diamant M., Tushuizen M.E., Sturk A. et al. Cellular microparticles: new players in the field of vascular disease? Eur J Clin Invest. 2004 Jun; 34 (6): 392-401.

20. Furie B., Furie B.C. Mechanisms of thrombus formation. N Engl J Med. 2008 Aug 28; 359 (9): 938-49

21. Tsimerman G., Roguin A., Bachar A. et al. Involvement of microparticles in diabetic vascular complications. Thromb Haemost. 2011 Aug; 106 (2): 310-21

22. Aharon A., Brenner B. Microparticles, thrombosis and cancer. Best Pract Res. Clin Haematol. 2009 Mar; 22 (1): 61-9.

23. Tzoran I., Rebibo-Sabbah A., Brenner B., et al. Disease dynamics in patients with acute myeloid leukemia: New biomarkers. Exp Hematol. 2015 Nov; 43 (11): 936-43.

24. Martinez M.C., Tesse A., Zobairi F. et al. Shed membrane microparticles from circulating and vascular cells in regulating vascular function. Am J Physiol Heart Circ Physiol. 2005 Mar; 288 (3): H1004-9.

25. Campello E., Spiezia L., Radu C.M. et al. Circulating microparticles in carriers of prothrombin G20210A mutation. Thromb Haemost. 2014 Sep 2; 112 (3): 432-7.

26. Campello E., Spiezia L., Radu C.M. et al. Circulating microparticles and the risk of thrombosis in inherited deficiencies of antithrombin, protein $\mathrm{C}$ and protein $\mathrm{S}$. Thromb Haemost. 2015 Dec 22; 115 (1): 81-8.

27. Breen K.A., Sanchez K., Kirkman N. et al. Endothelial and platelet microparticles in patients with antiphospholipid antibodies. Thromb Res. 2015 Feb; 135 (2): 368-74.

28. Dinkla S., Brock R., Joosten I. et al. Gateway to understanding microparticles: standardized isolation and identification of plasma membrane-derived vesicles. Nanomedicine (Lond). 2013 0ct; 8 (10): 1657-68.

29. Radu C.M., Campello E., Spiezia L. et al. Origin and levels of circulating microparticles in normal pregnancy: A longitudinal observation in healthy women. Scand J Clin Lab Invest. 2015 0ct; 75 (6): 487-95.

30. Luo S.S., Ishibashi 0., Ishikawa G. et al. Human villous trophoblasts express and secrete placenta-specific microRNAs into maternal circulation via exosomes. Biol Reprod. 2009 Oct; 81 (4): 717-29.

31. Katzenell S., Shomer E., Zipori Y. et al. Characterization of negatively charged phospholipids and cell origin of microparticles in women with gestational vascular complications. Thromb Res. 2012 Sep; 130 (3): 479-84.

32. Gonzalez-Quintero V.H., Jimenez J.J., Jy W. et al. Elevated plasma endothelial microparticles in preeclampsia. Am J Obstet Gynecol. 2003 Aug; 189 (2): 589-93.
33. Petrozella L., Mahendroo M., Timmons B. et al. Endothelial microparticles and the antiangiogenic state in preeclampsia and the postpartum period. Am J Obstet Gynecol. 2012 Aug; 207 (2): 140 e20-6.

34. Salem M., Kamal S., El Sherbiny W. et al. Flow cytometric assessment of endothelial and platelet microparticles in preeclampsia and their relation to disease severity and Doppler parameters. Hematology. 2015 Apr; 20 (3): 154-9

35. Meziani F., Tesse A., David E. et al. Shed membrane particles from preeclamptic women generate vascular wall inflammation and blunt vascular contractility. Am J Pathol. 2006 Oct; 169 (4): 1473-83.

36. Lok C.A., Jebbink J., Nieuwland R. et al. Leukocyte activation and circulating leukocytederived microparticles in preeclampsia. Am J Reprod Immunol. 2009 May; 61 (5): 346-59.

37. Ling L., Huang H., Zhu L. et al. Evaluation of plasma endothelial microparticles in preeclampsia. J Int Med Res. 2014 Feb; 42 (1): 42-51.

38. Patil R., Ghosh K., Satoskar P. et al. Elevated procoagulant endothelial and tissue factor expressing microparticles in women with recurrent pregnancy loss. PLoS One. 2013; 8 (11): e81407.

39. Pasquier E., De Saint Martin L., Bohec C. et al. Unexplained pregnancy loss: a marker of basal endothelial dysfunction? Fertil Steril. 2013 0ct; 100 (4): 1013-7.

40. Laude I., Rongieres-Bertrand C., BoyerNeumann C. et al. Circulating procoagulant microparticles in women with unexplained pregnancy loss: a new insight. Thromb Haemost. 2001 Jan; 85 (1): 18-21.

41. Aharon A., Katzenell S., Tamari T. et al. Microparticles bearing tissue factor and tissue factor pathway inhibitor in gestational vascular complications. J Thromb Haemost. 2009 Jun; 7 (6): 1047-50

42. Aharon A., Lanir N., Drugan A. et al. Placental TFPI is decreased in gestational vascular complications and can be restored by maternal enoxaparin treatment. J Thromb Haemost. 2005 Oct; 3 (10): 2355-7.

43. Goswami D., Tannetta D.S., Magee L.A. et al. Excess syncytiotrophoblast microparticle shedding is a feature of early-onset preeclampsia, but not normotensive intrauterine growth restriction. Placenta. 2006 Jan; 27 (1): 56-61.

44. Record M. Intercellular communication by exosomes in placenta: a possible role in cell fusion? Placenta. 2014 May; 35 (5): 297-302.

45. Orozco A.F., Jorgez C.J., Ramos-Perez W.D. et al. Placental release of distinct DNA-associated micro-particles into maternal circulation: reflective of gestation time and preeclampsia. Placenta. 2009 0ct; 30 (10): 891-7.

46. Vanwijk M.J., Svedas E., Boer K. et al. Isolated microparticles, but not whole plasma, from women with preeclampsia impair endotheliumdependent relaxation in isolated myometrial arteries from healthy pregnant women. $A m \mathrm{~J}$ Obstet Gynecol. 2002 Dec; 187 (6): 1686-93.

47. Messerli M., May K., Hansson S.R., et al. Fetomaternal interactions in pregnancies: placental microparticles activate peripheral blood 
monocytes. Placenta. 2010 Feb; 31 (2): 106-12.

48. Aharon A., Brenner B., Katz T. et al. Tissue factor and tissue factor pathway inhibitor levels in trophoblast cells: implications for placental hemostasis. Thromb Haemost. 2004 0ct; 92 (4): 776-86.

49. Marques F.K., Campos F.M., Sousa L.P. et al Association of microparticles and preeclampsia. Mol Biol Rep. 2013 Jul; 40 (7): 4553-9.

50. Laresgoiti-Servitje E. A leading role for the immune system in the pathophysiology of preeclampsia. J Leukoc Biol. 2013 Aug; 94 (2): 247-57.

51. Gardiner C., Tannetta D.S., Simms C.A. et al. Syncytiotrophoblast microvesicles released from pre-eclampsia placentae exhibit increased tissue factor activity. PLoS One. 2011; 6 (10): e26313.

52. Raghupathy R. Cytokines as key players in the pathophysiology of preeclampsia. Med Princ Pract. 2013; 22 Suppl 1: 8-19.

53. Shomer E., Katzenell S., Zipori Y. et al. Microvesicles of women with gestational hypertension and preeclampsia affect human trophoblast fate and endothelial function. Hypertension. 2013 Nov; 62 (5): 893-8.

54. Germain S.J., Sacks G.P., Sooranna S.R. et al. Systemic inflammatory priming in normal pregnancy and preeclampsia: the role of circulating syncytiotrophoblast microparticles. J Immunol. 2007 May 1; 178 (9): 5949-56.

55. Tesse A., Meziani F., David E. et al. Microparticles from preeclamptic women induce vascular hyporeactivity in vessels from pregnant mice through an overproduction of NO. Am J Physiol Heart Circ Physiol. 2007 Jul; 293 (1): H520-5.

56. Ambros V., Lee RC. Identification of microRNAs and other tiny noncoding RNAs by cDNA cloning. Methods Mol Biol. 2004; 265 131-58.

57. Esquela-Kerscher A., Slack F.J. Oncomirs microRNAs with a role in cancer. Nat Rev Cancer. 2006 Apr; 6 (4): 259-69.

58. Morales-Prieto D.M., Ospina-Prieto S., Chaiwangyen W. et al. Pregnancy-associated miRNA-clusters. J Reprod Immunol. 2013 Mar; 97 (1): 51-61.

59. Hannafon B.N., Ding W.Q. Intercellular communication by exosome-derived microRNAs in cancer. Int J Mol Sci. 2013; 14 (7): 14240-69

60. Stenqvist A.C., Nagaeva 0., Baranov V. et al. Exosomes secreted by human placenta carry functional Fas ligand and TRAIL molecules and convey apoptosis in activated immune cells, suggesting exosome-mediated immune privilege of the fetus. J Immunol. 2013 Dec 1;
191 (11): 5515-23.

61. Thum T., Gross C., Fiedler J. et al. MicroRNA-21 contributes to myocardial disease by stimulating MAP kinase signalling in fibroblasts. Nature. 2008 Dec 18; 456 (7224): 980-4

62. Thum T., Galuppo P., Wolf C. et al. MicroRNAs in the human heart: a clue to fetal gene reprogramming in heart failure. Circulation. 2007 Jul 17; 116 (3): 258-67.

63. Mitchell P.S., Parkin R.K., Kroh E.M. et al. Circulating microRNAs as stable blood-based markers for cancer detection. Proc Natl Acad Sci U S A. 2008 Jul 29; 105 (30): 10513-8.

64. Hunter M.P., Ismail N., Zhang X. et al. Detection of microRNA expression in human peripheral blood microvesicles. PLoS One. 2008; 3 (11): e3694.

65. Dangwal S., Thum T. microRNA therapeutics in cardiovascular disease models. Annu Rev Pharmacol Toxicol. 2014; 54: 185-203.

66. Diehl P. Fricke A., Sander L et al. Microparticles: major transport vehicles for distinct microRNAs in circulation. Cardiovasc Res. 2012 Mar 15; 93 (4): 633-44.

67. Mittelbrunn M., Gutierrez-Vazquez C., Villarroya-Beltri C. et al. Unidirectional transfer of microRNA-loaded exosomes from $T$ cells to antigen-presenting cells. Nat Commun. $2011 ; 2: 282$

\section{About the authors:}

Anat Aharon - PhD, Head, Microvesicles Research Laboratory, Thrombosis and Hemostasis Unit, Department of Hematology, Rambam Health Care Campus, P.0. Box 9602, Haifa 31096, Israel. Phone: +972-54-8004600. Fax: +972 4777 3886. E-mail: a_aharon@yahoo.com

Benjamin Brenner - MD, Professor, Department of Hematology and Bone Marrow Transplantation, Rambam Health Care Campus, Haifa, Israel; Bruce Rappaport Faculty of Medicine, Technion, Israel Institute of Technology, Haifa, Israel.

\section{Сведения об авторах:}

Анат Аарон - PhD, руководитель лаборатории по исследованию микровезикул, отдел тромбоза и гемостаза, Отделение гематологии, Медицинский городок Рамбам. Адрес: а\я 9602, Хайсра 31096, Израиль.

Бенджамин Бреннер - проф., отделение гематологии и трансплантации костного мозга, Медицинский городок Рамбам, Хайсра, Израиль. 